\title{
Teaching Somali Children: What Perceived Challenges Do Somali Students Face in the Public School System?
}

\author{
Teresa M. Kruizenga \\ University of Wisconsin - River Falls \\ 410 S. Third Street, River Falls, WI 54022-5001, USA
}

Tel: 1-715-425-3738_E-mail: teresa.kruizenga@uwrf.edu

\begin{abstract}
This article reviews the literature on the experience of Somali immigrant children and their lives at school. A semi-structured, open interview provides insights into the historical and personal backgrounds of Somali children. Data explores issues of language acquisition, religion and familial connections in relation to their schooling experience. Suggestions are offered to educators for improving the educational experience for Somali children and families.
\end{abstract}

Keywords: Somali refugees, Bilingual education, Immigrant education 


\section{Introduction}

Through an interview with Mohamed Saeed (pseudonym), I learned that February 16, 1993 was a date he and his family will never forget. This is the day that Mohamed, his wife and their seven children arrived in the United States, one of the first immigrant families from Somalia to arrive in the area. "First of all, I want you to know that I thought I would never immigrate [sic] from my country. It is really an experience in life-life is unpredictable" (personal conversation with Mohamed). Mohamed would be the first to tell you that he and his family were one of the lucky ones. As I listened to his story, of the escape from Somalia, it is hard to imagine that anyone could think of themselves as being lucky after experiencing such violence. His description of the city in which he lived being in flames, "the shelling, the shooting, and the horrors of a civil war” happening right outside his door (Fared, 2004, p. vi), would make anyone of us wonder how lucky one really is. Mohamed and his family felt lucky to be alive. After coming to the U.S., Mohamed was not able to get a job in his previous profession, banking. Five of his seven children were attending a public school in the area. The principal at the school in which his children first attended noticed that Mohamed could speak English. With no Somali translators available the schools were desperate to find someone who could help these new immigrants, the principal invited Mohamed to come to the schools and help. Mohamed turned down the position. It was not until after he received encouragement from a professor at a nearby university that Mohamed went back to school to become a bilingual teacher of Somali. A few years later he returned to the university to earn a master's degree as well.

Google Mohamed Saeed (pseudonym) and you will get 4,800,000 hits. However, Mohamed, author and educator, is one in a million (or shall I say 5 million). Mohamed, an extraordinary man, who has dedicated his life to advocating for Somali children and families agreed to meet with me to discuss Somali culture and the experiences of Somali children within schools in the United States. Was I nervous calling a strange man's phone number with no real assurance that he was indeed the man I was looking for? Yes would be an understatement. Narrowing my Google search to Mohamed Saeeds' living within the area, revealed to me, through the magic of the internet, a home address and phone number with no guarantee that this was, in fact, the person I was looking for. Worried that I might appear as a stalker or worse a telemarketer, I dialed the number. Despite my trepidation, the voice on the other end reassured me that indeed I had found the right man. This paper is an attempt to better understand the Somali culture and the experiences of Somali students within US schools through a literature review and the voice and words of Mohamed.

As you can see in table 1, prior to 1991 very few people of Somali decent resided in the United States. However, with the onset of the civil war in 1991 Somalis were fleeing their country in great numbers. The privileged and the educated people left first (Farid, 2004). Their connections, resources, and language skills provided them with opportunities to escape the bloodshed and horrors of the civil war. Since that time tens of thousands of Somali refugees have relocated to the United States making them the largest African refugee group in this country and one of the most unique sets of newcomers to enter this nation (Condon, 2006, as cited in MPR News Q retrieved September 24, 2009). "Minnesota has an estimated 40,000 Somalis, with most living in Minneapolis or St. Paul” (Bigelow, 2007, p. 11). This 


\section{Ml Macrothink}

International Journal of Education

ISSN 1948-5476

2010, Vol. 1, No. 1: E12

influx of people from a very unique culture, arriving with little knowledge of English, has challenged the current school system to address the social, emotional and educational needs of the Somali children and families.

Table 1.

\section{Somali Immigration to Minnesota}

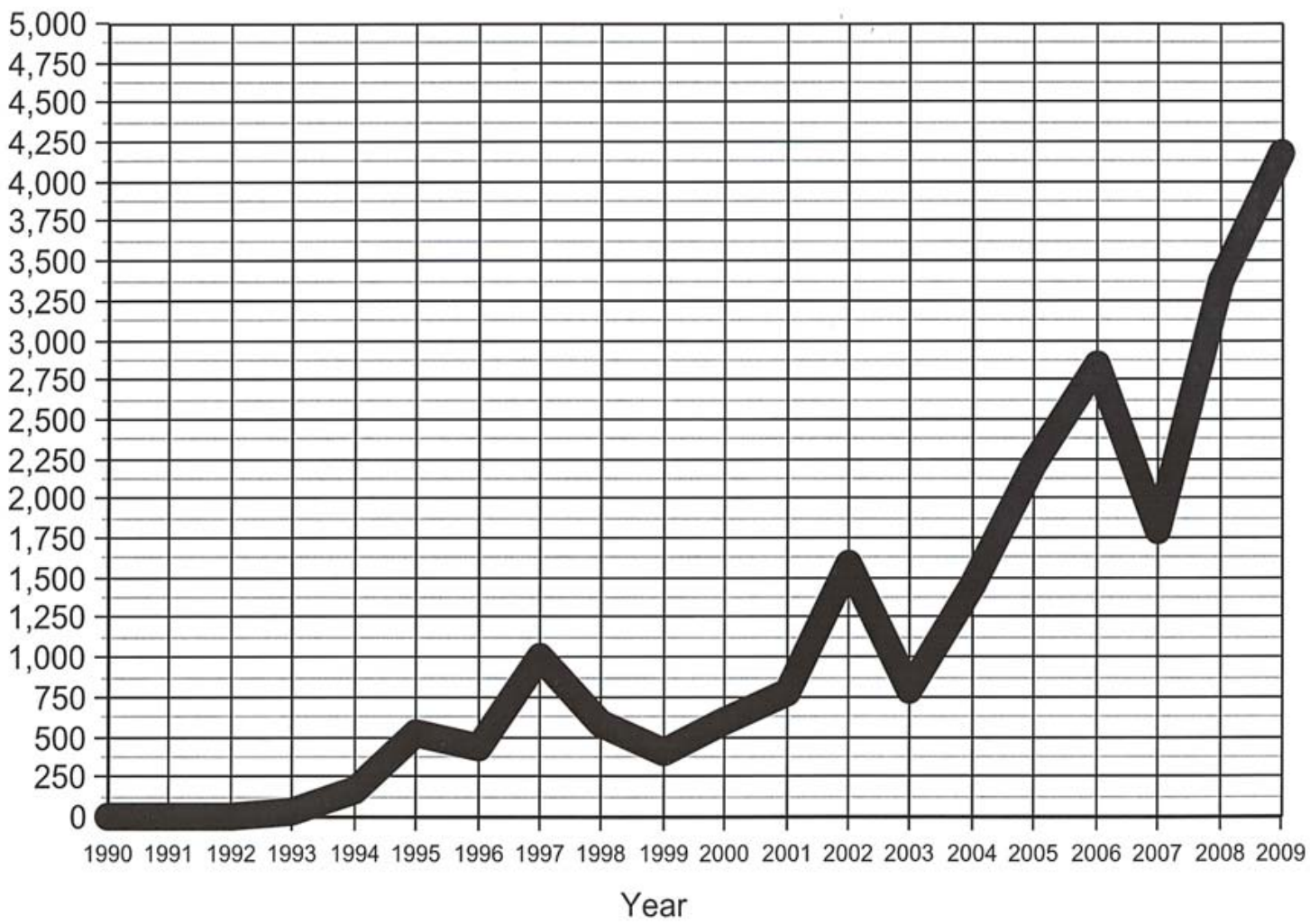

From Dept. of Homeland Security: State Demographic Center

Somalis bring with them a combination of a minority culture, religion, and race that provides a different type of immigration issue. Somali values and culture have been passed on from one generation to the next through the rich oral tradition of the Somali people. The rich oral tradition, the fact that the Somali language did not have a written form until 1972 (Putman \& Noor, 1993), the closing of schools due to the civil war and the lack of educational opportunities in refugee camps often mean that Somali students enter schools in the United States with little to no formal schooling. In addition to arriving with little knowledge of English, the "day-to-day lives and schooling experiences of these youth are complicated by social pressures that are contradictory to their faith, such as dating, premarital sex and alcohol use” (Zine, 2001, p. 401). Thus, demonstrating that many problems faced by Somali children in school, stem from cultural differences different from other immigrant populations.

"In the world of public education, immigrant and refugee [students] are often characterized by what they lack at school” (Bigelow, 2007, p. 7); students are often viewed from a deficit model. For immigrant students where teachers may know very little about the lives of their 
students outside of school, an attempt to get to know their students and understand that they come from a rich cultural and cognitive background is a crucial first step in creating a bridge between home and school (Moll et al., 1992; Gonzalez et al., 1993; 2005). The process of immigration entails a tremendous amount of stress for newcomers (Portes \& Rumbaut, 1996). The worldviews and cultural ways of being for individuals are often threatened when they come into contact with the dominant culture in their host country. Previous ways of being and relating to others become vulnerable as newcomers begin to navigate through the demands of their new societal contexts (Oikonomidoy, 2007). Structural demands such as race, religion, language, and status influence the patterns of adaptation of new comers. Thus, as teachers we must care enough to attempt to learn, understand, and know our students' political, historical and personal situations -'funds of knowledge' (Moll et al., 1992); taking the important steps to use what the students bring from their backgrounds into the classroom. Ladson-Billings (2006) states, "students [of color] look to schools as the vehicle for social advancement and equity” (p. 32). In other words, reinforcing the importance of understanding the experiences of immigrant students is a primary importance for educators.

I seek to explore and understand the educational experience of Somali children by examining the research of the education of Somali students in the United States, Canada and the United Kingdom and through a semi-structured interview with Mohamed Saeed. Focusing on this specific group is important for at least three specific reasons. First, examining the education of this community is necessary to give an overview of the issues and unique cultural perspective that these new immigrants bring to the United States. Second, the examination of current research on Somali children's experiences in formal schooling is needed to determine future directions in education reform to meet the needs of refugee children, and, finally, to establish a knowledge base to determine future directions for research. In this paper, I will explore the various explanations for the struggle, successes, and educational experiences of Somali students in formal schooling.

\subsection{History of Somalis Immigrating to the U.S.}

Somalia is located in the Horn of Africa and is a little smaller than the state of Texas. Somalis are an ethnic group that is almost entirely Muslim (Wilder 2000). Most of Somalia is rural and nearly $80 \%$ of the people are pastoralists, agriculturalists, or agro pastoralists. The vast majority of people are ethnic Somalis who practice Islam and speak dialects of Somali (Putman, 1993). Their society is clan based with most families having many children and including extended family members in the household (Masny, 1999). Oral language is the main form of communication with no written language until 1972 (Crabb, 1996).

"Between 1991 and 1993, the war created more than 1.5 million refugees" (Gardner, 2004, p. 81). Somalis were forced to leave their country due to influences of colonialism, communist military dictatorship, and religious persecution. Years of oppression eventually drove the Somali people to war. The civil war had a devastating effect with an estimated 400,000 people being killed, dying of famine or disease; almost $45 \%$ of the people were displaced inside the country or fled to other countries (Putman, 1993). Desperate for a place of peace and prosperity Somali refugees flocked to Minnesota. Due to word of mouth, Minnesota 
was proclaimed as the place of good employment, good schools, excellent refugee services, and most importantly the hope of peace and being reunited with loved ones.

Thus, Minnesota became the destination of hope for many Somali refugees. According to Minnesota Public Radio, "Minnesota saw its third largest influx of immigrants in a quarter century in 2004, with immigrants from Somalia leading the pack. Minnesota is $16^{\text {th }}$ nationally, but it is first in the number of Somali immigrants. Ohio was a distant second (Condon, 2006, as cited in MPR News Q retrieved September 24, 2009). There is a tremendous gap between Minnesota educators and the Somali immigrant students. With the sudden influx of Somali children entering the schools in Minnesota it is imperative that we take the first steps toward understanding and implementing a culturally relevant curriculum that meets the needs of these students. In the words of Mohamed Fared (2004), "Learning about another culture is a life-long undertaking. The first step in this rewarding journey is to contrast elements of one's own culture to the other" (p. viii). This paper is an attempt to take those "first steps" to learn about the Somali culture and the experience of Somali children attending schools in the U.S.

\section{Methodology}

The research is interpretive and qualitative in nature. The data for this paper came from a literature review and an interview with a Somali immigrant and educator. The focus of this paper is on research examining the schooling experiences of Somali youth with limited formal schooling and a semi-structured interview with Mohamed Saeed from a larger Somali community study. I began a search of existing literature using the general terms "Somali," "refugees," "immigrants," "Muslim,” in combination with "students,” and "education,” I searched electronic databases such as Educational Resources Information Center (ERIC), Educational Full Text, and Social Sciences Abstracts using the following keywords: Somali refugees, bilingual education, and immigrant education. I also examined the reference sections of the books, book chapters, and articles of this literature. I narrowed the search to literature that addressed the education of Somali students in a formal schooling experience. I initially intended on limiting the research to include research within the United States only; however, after seeing how little research was out there addressing the educational experience of Somali youth I broadened my research to include Canada and the United Kingdom as well. This methodology and range of data sources were used to understand and recognize the complexity of the Somali experience.

I found much published research centers on medical and psychiatric needs. However, I did not include articles from medical journals in this review or studies published before 1997.

I first coded articles and book chapters using the keywords, "identity," "language acquisition,” “stereotype,” "acculturation,” “cultural consonance,” (or dissonance), "beliefs,” and others. From there, I looked for patterns by which to group keywords into themes that addressed my question. Thus, keywords used are "language acquisition," "parental and community factors," and "Somali student experience.” 
In general, my literature search revealed that these studies focused mainly on cultural explanations or structural explanations. Each study used different questions, used different perspectives, and varied in completeness when describing the Somali experience in a formal school setting. The studies primarily used literature review, case study and interviews. When Somalis immigrated to the United States they found a culture "that is about as different from [Somalia] as two places on earth can be” (Farid, 2004, p. 19). In their native culture their religion, cultural traditions, parenting, and schooling were congruent with the society they knew. Because American culture is so different from what is known for the Somali people, it is no wonder that they encountered many difficulties within the school system. In order to better understand the experience of a Somali immigrant, culture and how that impacts teaching and learning I thought it was imperative that I heard the stories of the Somali people as well.

Mohamed Saeed (pseudonym) is not only an immigrant from Somalia he is a teacher and author as well. I was first introduced to Mohamed Saeed through his book. I read the text and found it was not only informative, but a moving human story about overcoming all odds. His story inspired and compelled me to meet him in person. I was confident that his life experiences could not only help me to understand the experience of a Somali immigrant, but to help current and future teachers alike. I Googled my participants name in hopes of finding a place of business or a professional office that I could contact him at. However, all I was able to locate was a home address and home phone number. My cultural background dictated that it would be rude or invasive to call someone you had not even met at their home to ask for an interview. I decided to contact different Somali leaders at various community centers in hopes that I would be granted an interview. Meetings had been set up, only to be cancelled. Thus, it wasn't until after other interview participants had not worked out that I decided to give Mohamed a call. I called him at his home and simple asked if he was the author that I was looking for. He confirmed and, to my great surprise, he agreed to meet with me as well as be interviewed.

We agreed to meet at a restaurant not far from his home. As I pulled into the parking lot, my eyes immediately began to search for a parking spot. The sunny, 48 degree, November day brought many people out to enjoy what could possibly be the last warm day of the year. Light and dark colored cars filled the lot, absorbing the suns heat. The bright red and yellow “All Day Buffet-Every Day” sign in the right front window, welcomed families who had gathered inside to enjoy a Sunday afternoon with families and friends. I sat outside, on a red vinyl covered metal chair, looking for a man who would fit the description given to me on the phone earlier that day: an older man (he stated old) with a white beard. I was fifteen minutes early. My goal was to conduct a one-hour semi-formal interview with open-ended questions. I checked my digital voice recorder, patted the extra batteries in my jacket pocket. I glanced over my questions one last time, trying to make sure that all my questions addressed and pointed to what I had come to learn: What perceived challenges do Somali students face in the public school system? To what do you attribute these difficulties to? What do you feel the schools could do to alleviate these problems? The insights gained from these questions could help me as a teacher educator, school teachers and administrators to be 
more informed and accommodate the needs of Somali learners.

I am currently an instructor in the Teacher Education Department at the University of Wisconsin-River Falls. As a woman who appears to be white and middle-aged I have much to learn about the Somali culture. This lack of understanding of the Somali culture concerned me as three of our six partner schools have a large population of Somali pupils (i.e., 30\%, 25\% 15\% Somali speaking pupils). The Teacher Education Department is extremely proud of the strong partnerships established and maintained over the years with the schools in the Twin Cities area. As a result of this partnership, our candidates are welcomed into the schools and classrooms with open arms. This opportunity affords our prestudent teachers an intense field experience component while simultaneously learning methods in each of the core subject areas. The prestudent teachers spend half the semester in the college classroom setting getting instruction in theory and methods, the other half of the semester prestudent teachers are placed in an elementary classroom. While the prestudent teachers are in the elementary classrooms we (the instructors) are in the elementary classroom setting with them as well (i.e., observing master teachers, observing prestudent teachers, conferring, modeling lessons in large and small groups, etc). This access to the elementary school gives me and our prestudent teachers a front row seat to learn how to tap into culture capital to build meaningful learning opportunities for pupils. However, to build these meaningful connections for prestudent teacher and pupils alike, we need to learn more about the students and their community. In the following section, I will present a review of literature that I hope initiates the process that allows for meaningful connections necessary for teachers to understand the Somali experience. The first theme will address language acquisition and how it is relevant to the Somali educational experience. Then I will review literature related to parental and community factors. Finally, I will evaluate literature linked to the Muslim student experience.

\section{Literature Review}

\subsection{Language Acquisition}

This section will not cover all of the literature related to language acquisition. I have chosen articles that relate to the Somali educational experiences because like Masny (1999) I believe that literacies (oral and written forms) are interwoven with religion, gender, race, culture, identity, ideology and power. Gee (1991) states "literate behaviors incorporate ways of talking, reading, writing, and valuing, that is, ways of being in the world. Most of the studies that I looked at pointed to a close link between language and identity as well as indicated that students who had acquired good English language skills achieved at higher levels academically and socially.

Masny (1999) wrote about how school-based literacy practices are often less accessible to non-mainstream children since their personal and community literacies, related to their home culture and with their characteristic values and ways of making sense, are seldom represented in the culture of the school. These differences between home socialization and school expectations can often contribute to school failure as well as have a negative effect on the children's identity formation. Masny suggested the use of a language experience approach, 
which draws on the students' personal experiences to teach and increase vocabulary and reading/writing capabilities. The author called for teachers to learn about the cultures and experiences of their Somali students in order to facilitate their acquisition of language and academic skills as well as provide the children with a sense of voice and a link between school and community cultures.

Kapteijens and Arman (2004) discussed how children's language retention and acquisition related not only to academic achievement, but also to their success with acculturation and a sense of continuity with their parents and others from their native country. Bilingual children had the highest test scores and high self-esteem. They also had the fewest conflicts with their parents. Bigelow (2007) found a strong correlation between native language proficiency that linked a close personal tie to their parents; she believed that this gave youth access to many sources of social capital. This social capital in her opinion could possibly lead to the growth of cultural capital and is thus linked to social mobility. Kapteijens, Arman and Masny criticized the tendency for schools to adopt an English immersion only approach as it increases cultural dissonance and can cause children to lose their native language.

Oikonomidoy, (2007) revealed that all participants in the study mentioned that, upon arrival in the US, they did not know how to speak English. For some of them, having a classmate from Somalia was a source of relief and encouragement. The inability to speak the language meant exclusion from academic and social functions. Similar to the students in Valede's (1998) study, the participants in this study initially struggled to learn English. However, they worked hard on their English language skills and used multiple resources to accomplish this. In Olsen's (1997) study, participants were also aware of how their pronunciation affected the perceptions of their peers. They worked hard on their accents in order to avoid being targeted for the way in which they spoke English. It seems that the students did 'invest' (Norton, 2000) in language learning, knowing that it was necessary milestone in the potential of acceptance by peers and the progression in the academic life at school.

In summary, recent researchers consider school settings that use cultural elements from the students' native countries important to facilitate language acquisition. Language is a major barrier to learning, until children become competent in speaking reading, and writing English they will struggle in school. To improve school resources, administrators need to look carefully at the recent research on language acquisition, and teachers must familiarize themselves with the Somali experience. Findings support that identity and language learning are affected by discrimination, cultural dissonance and the reception that refugees receive from their host society.

\subsection{Parental and Community Factors}

Intense conflicts between parent and child are often cited as an adjustment problem for immigrant and refugee children as well as having significant family responsibilities (Lee, 2001; Lew 2006). These responsibilities sometimes interfere with a student's ability to be successful academically. In contrast, Bigelow (2007) found Somali parents within her study 
to be an asset to the student's educational success. For example, one student in the study was the oldest of 10 children and some people may assume that being the older adolescent she would be expected to help with the family financially by working or taking charge of domestic duties. However, the family worked together as a unit to support each other and the expectation in the family is that each student will study; that education is of utmost importance. Another key finding was that the mother never allowed the children to make decisions or assume adult responsibilities due to her lack of skill in English, something often reported in immigrant families (Gonzales, 2003). Instead the mother used Somali friends and family members. Bigelow also reveals that the mother within her study maintains a close monitoring of the children's educational success. Thus, indicating that parental involvement and close monitoring are important for academic success. Masny's (1999) research supports Bigelow's findings. She found that Somalis gain their strength in group membership and group activity in such a way that even working alone or living alone is uncommon in the Somali culture. However, Masny quoted school teachers as saying that the Somali families did not care about their children's school progress. In this case, stereotypes and prejudice may have caused teachers to hold mistaken opinions about the Somali students as these comments opposed behaviors and interviews held by the Somali parents within her study.

Kapteijns and Arman (2004) report that Somali parents often have a fiercely positive attitude toward education. When this is shared by the youth, this correlates with student education success. Parental involvement in their children's education-showing interest in or supervising their homework can undo the negative impact of substandard schools Somali students in urban settings often find themselves in. Bigelows research revealed parents who sought outside support for their children to aid with homework. This parental support and involvement, research suggests, as well as the ability to keep their children somewhat grounded in their own ethnic culture (while they become competent in the mainstream domain), have positive results for school achievement.

Despite these favorable findings the Somali Community Needs Assessment Project (2001) reports that some Somali parents thought American culture had changed their children in less than favorable ways. Parents in a focus group stated that some Somali youth have abandoned customs and traditions such as praying five times a day, fasting during the month of Ramadan, or wearing traditional attire. Surprisingly, there were some participants in the focus groups who welcomed government help in disciplining their children. One parent said he was willing to have the authorities send his child back to the refugee camp if the child commits more than three crimes because keeping him in the United States would do more harm than good. They also feel that living in the United States has changed the way Somali families deal with conflicts. The law has replaced elders in the role of ironing out family differences. In Somali culture, elders are regarded as experts in the family matters because they know how to counsel and appease all parties involved. The participants in the focus groups expressed their desire to maintain this traditional system of conflict management and dispute resolution.

In summary, parental factors of misunderstanding, conflicting cultural beliefs, and language 
difficulties to what Rumbaut and Portes (2001) term dissonant acculturation, in which parents lag behind their children's acquisition of the language and culture of their new home. Parents may feel a loss of control. Family conflicts may increase, with an ensuing loss of the sense of safety and security on the part of the children.

\subsection{Somali Student Experiences}

Zine (2001, 2001) explained that students within Canadian schools negatively stereotype Muslim and that schoolchildren often tease foreign-born peers about their Arab names. Muslim students are often alienated for displaying outward signs of their religion, such as wearing hijab and fasting during Ramadan. Zine reported that most Muslims consider terrorist activity as criminal, and Muslim students reported that they had to defend themselves against being called terrorists. Gilbert (1999) conducted research which sought to examine the experiences of 30 Muslim children in a primary school in north-west Britain. Findings demonstrate how the process, procedures and rationale of school policies and administrators continue to privilege whites and discriminate against non-whites, and more specifically Muslims. His discussion highlights that analysis of organizations requires a far more refined and sophisticated understanding of institutional racism (including institutional discrimination of the grounds of religion or belief) which permeates within and between organizations. These experiences of discrimination as a result of their religious practices, for example, clothing, daily prayer, and refusal to date are not the only issues that Muslim students address.

Bigelow (2008) explores the issues of race and religion as they pertain to adolescent Somali immigrants and their lives at school. She reports that Somali parents and community leaders worry that the youth are forgetting their culture, their language, and most important, their religion. Somali students are adopting the social, linguistic, and cultural codes of the dominate group and through this process Somali youth are reconstructing national and religious identities that challenge traditional versions of what it means to be a Somali Muslim teen.

\subsection{Discussion of Literature}

Overall, the literature that is reviewed here emphasizes several important points that apply to Somali youth. Language is a major barrier to learning, until children become competent in speaking reading, and writing English they will struggle in school. Cultural elements from the students' native countries are important components to use to facilitate language acquisition. To improve school resources, administrators need to look carefully at the recent research on language acquisition, and teachers must familiarize themselves with the Somali experience. Findings support that identity and language learning are affected by discrimination, cultural dissonance and the reception that refugees receive from their host society. Parents may feel a loss of control. Family conflicts may increase, with an ensuing loss of the sense of safety and security on the part of the children. Muslims may find fitting in at a Judeo-Christian public school is very difficult. Somali parents and community leaders worry that the youth are forgetting their culture, their language, and most important, their religion. In this section, I will review themes offered by Mohamed in a semi-structured interview. 


\section{Interview Data}

\subsection{Observations}

To analyze my data I listened to the interview in its entirety three times before transcribing. I then highlighted and took notes of the transcriptions. During the interview I made a couple of observations. One was that the participant was very adamant about his Islamic faith. As he spoke of his religious beliefs his voice was unwavering. It appeared to be very important to him that I understood the Islamic faith and how this faith is at the very core of who the Somali people are. Mohamed indicated that if I want to truly understand how best to educate Somali children I need to know and understand their religion. It also appeared to be very important that I understood that the Islamic faith does not promote or condone death, killing, or harm of any type in the name of Allah.

Another observation made was the extreme kindness, generosity and hospitality that was shown to me. Because we had met at a restaurant I had planned on buying dinner for my participant. I wanted to pay because of the gift of time and expertise he was willing to share. No matter how many times I profusely offered, he insisted on paying because "I" was his guest and it was the Islamic way. He repeated this multiple times during our time together that this is what Somali people do.

\subsubsection{The Importance of Language}

This brief section sets out to highlight a few significant factors relating to "language" and its connection to culture and identity.

“The Somali language did not have a written form until 1972” (Putman \& Noor, 1993, as cited in Fared, 2004, pg. 4) Thus, the rich oral tradition of the Somali people is an important aspect when discussing the values of the culture. Poetry, stories, and proverbs have been passed from one generation to the next (Fared). Because of this rich oral tradition older Somali people may have grown up never reading a single word, but can memorize large volumes of information. Mohamed shared with me that in Somali many people can listen to large volumes of information and memorize it completely. Because of not being exposed to a written language, parents of Somali children may not read or write in Somali or any other language. Mohamed stated the following:

Before this our language was a spoken language only. When students are reading and writing it is more difficult for them. So I always recommend to teachers to pay attention to this. People should know how to read and write. For Somali to be successful they need to learn how to read and write in both Somali and English (M. Saeed, personal communication, November 2009).

Not only does Mohamed feel that it is important for Somali children to learn to read and write in English he states that it is equally important for them to learn to read and write in Somali. The importance of Somali students learning Somali and English simultaneously has three distinct purposes according to Mohamed. One purpose is that education is viewed as important to the success of the Somali people. "Education is considered invaluable" 
(Fared,2004, p.2), and is not taken for granted. Literacy is a critical part of this success to the Somali people. But, because of extreme circumstances during the civil war education opportunities have been limited and thus children and adults alike may not read or write in Somali.

The importance of learning and maintaining the language in order to continue familial relationships and Somali traditions is expressed as a priority and state of emergency by Mohamed. The conversation below illustrates the population, he believes, should be placed in priority of receiving current resources within the school system.

And also when people stay longer they are getting married. . . having babies. And these babies don't have the resources for their first language and these are the most needed group now. They need more tradition. Because some of the family members don't . . . they don't speak English of course. And the kids don't speak Somali. They cannot communicate. This group of the younger generation that was born here ... they need more than those who are coming because they [recent immigrants] have more resources now and they understand the traditional ways (M. Saeed, personal communication, November 2009).

Above, Mohamed is expressing a concern to the possible loss of the Somali language. He associates the loss of language to the loss of a culture, family ties, and ultimately the identity of the Somali people. His voice reveals a sense of deep sadness as he talks about how more and more youth are being lost to the American ways. He believes that students who are instructed in Somali are less likely to lose their first language and thus hang on to the traditional Somali culture and continue to support and nurture the important familial bonds. "It is important especially for the family. . . for the family are talking together." Mohamed sees these family connections important in helping children to understand their culture and identity; however, not being able to speak the same language that your parents, grandparents, aunts, uncles etc., can cause great divides between family and child. This disconnect could result in the dividing of a family because they cannot understand each other, but the implications are much greater to the Somali culture.

Lastly, when it comes to maintaining the home language, Mohamed believes the students who can speak, read and write their native language can transfer their knowledge learned in Somali to English; thus, creating a bridge between prior knowledge to current knowledge. They need to continue practicing the speaking, reading and writing of their native language.

Actually, I will give you a case as a teacher. . . something that we've already experienced. . . I did it. .. with a colleague of mine. A Somali bilingual teacher. We were teaching first grade. They brought kids . . . a number of kids who don't speak Somali. Reading [English] was confusing, difficult for them and they are first grade. They. . . the teachers. . . um. . . brought them to us and asked what do we do. So what we did is ... Let's teach them first language [Somali] and pair them with those who speak the language. This was a clinical. . . crucial. . . crucial . . .we measured their feelings. How are they responding to . . . Every week there was 15\% progress. . . 20\% progress. . .by 3 months they were reading Somali and speaking 
Somali and reading in English. They were talking with their peers. We could see them talk together. The moral is the importance of learning Somali. This was a real experience (M. Saeed, personal communication, November 2009).

As you can see from the above quote, language was used to advance these first grade students academically. Even though these students were born here in the United States, English speaking only, Mohamed taught the children how to speak Somali using peers and then taught the children to read and write Somali and English simultaneously. In this section, I will review recommendations offered in the research reviewed, followed by gaps in current literature that suggest directions for important future research.

\section{Implications for Practice}

Researchers suggest that Somali students, to acculturate successfully, must merge new and native cultures in an additive assimilation strategy. Students should be engaged in learning/researching about their own identities and those of their classmates. All students should learn about how radicalization occurs at schools and in communities (Bigelow, 2008). Researchers find that retaining one's native language helps to maintain family and cultural ties that are important to one's identity and self esteem.

Social support is important for Somali parents as well as youth. Researchers have suggested that parents be welcomed and informed by school personnel. To overcome prejudice and discrimination, Somali youth need support at the structural and personal levels. Teachers need to confront their own attitudes toward immigrant and refugee children and create classrooms in which 'funds of knowledge' is respected from all children (Moll et al., 2005).

\section{Gaps in the Research}

There are several gaps in the literature. My literature search showed that research in the experience of Somali youth in formal schools is thin. I noticed that the studies that I did find were similar in methodology. All but one of the studies were qualitative case studies that involved semi-structured interviews. This provided rich experiential details, but often can't be generalized across programs and institutions.

Aside from stressing language acquisition and imploring the teachers to use a more culturally relevant pedagogy I'd like to see research addressing academic achievement in math, science, and language arts for Somali students. Bigelow and Zine did a nice job of addressing the difficulties of being Muslim in a Judeo-Christian culture; however, I think more studies need to be written to address the strong link between religion, culture, race and identity.

\section{Conclusion}

Mohamed's interview paired with research gives teachers and schools insights into possible ways to help Somali children succeed. Mohamed repeated multiple times the need for communication and the key to successful communication, in his opinion, is bilingual support. Schools need to think about adding bilingual services not only to help students learn English and help with parental communication, but to create meaningful academic connections, maintain language to support culture, identity, and familial bonds. 
Mohamed emphasized that teachers need to understand the students' backgrounds. Many times Somali students come here with very little or no formal education. This information has important implications for educators. It is crucial for these students, from the first day of school, to know that are accepted and valued members of the learning community. Teachers need to value the knowledge that they bring to the learning community versus seeing them as academically deficient. Mohamed also wants schools to give them the time and space they need for their daily prayers. Schools and teachers need to take the time to understand these students in order to lead them to higher education.

\section{References}

Alitolppa-Niitamo, A. (2004). Somali youth in the context of schooling in metropolitan Helsinki: A framework for assessing variability in educational performance. Journal of Ethnic and Migration Studies , 81-106.

Baker, C. (2000). The care and education of young bilinguals. New York: Multilingual Matters LTD.

Bigelow, M. (2008). Somali adolescents' negotiation of religious and racial bias in and out of school. Theory Into Practice, 27-34.

Bigelow, M. H. (2007). Social and cultural capital at school: The case of a Somali teenage girl. Literacy Institute at Virginia Commonwealth University (pp. 7-22). Richmond, VA: N.R.Faux (Ed.), Low-educated adult second language and literacy acquisition proceedings of symposium.

Borstein, M. \& Cote, L. (2004). Mothers' parenting cognitions in cultures of origin, acculturating cultures, and cultures of destination. Child Development, 75(1), 221-235.

Carolan, M., Bagherinia, G., Juhari, R., Himelright, J., \& Mouton-Sanders, M. (2000).Contemporary Muslim families: Research and practice. Contemporary Family Therapy, 22(1), 67-79.

Carter, R. (1999). Counseling Muslim children in school settings. Professional School Counseling, 2(3), 183-188.

Coleman, M.\& Ganong, L. (Ed.). (2004). Handbook of contemporary families: Considering the past, contemplating the future. Thousand Oaks, CA: Sage.

Collet, Bruce A. (2007). Islam, national identity and public secondary education: perspectives from the Somali diaspora in Toronto, Canada. Race Ethnicity and Education, 10(2), 131-153.

Crabb, Ruth. (1996). Working with Hassan. Multicultural Teaching to Combat Racism in School and Community. 14(2), 22-25.

Department of homeland security: State demographic center [Data file]. Available from Department of homeland security [Online] Available: http://www.demography.state.mn.us/resource.html?Id=18679

Faragallah, M.; Shumm,W. \& Webb, F. (1997). Acculturation of Arab-American immigrants: 
an exploratory study. Journal of Comparative Family Studies, 28:3.

Farid, M. (2004). Accommodating and educating Somali students in Minnesota schools. St. Paul, MN: Hamline University.

Gardner, J. (2004). Somalia the untold story: the war through the eyes of Somali women. Sterling, Virginia: Pluto Press.

Gehrke-White, D. (2006). The face behind the veil: The extraordinary lives of Muslim women in America. New York: Kensington.

Gilbert, D. (2004). Racial and religious discrimination: the inexorable relationship between schools and the individual. Intercultural Education, 253-266.

Gonzalez, N., Moll, L.C., \& Amanti C. (2005). Funds of knowledge: Theorizing practices in households and classrooms. Mahwah, New Jersey: Lawrence Erlbaum Associates

Hodge, D. R. (2002). Working with Muslim youths: Understanding the values and beliefs of Islamic discourse. Children \& Schools, 24(1), 6-20.

Kahin, Monamed H. (1997). Educating Somali children in Britain. Staffordshire, England: Trentham Books.

Kapteijns, L. (2004). Educating immigrant youth in the United States: an exploration of the Somali case. Bildhaan An International Journal of Somali Studies, (4) 18-43.

Ladson-Billings, G. (2006). From the achievement gap to the education dept: Understanding achievement in the U.S. schools. Educational Researcher, 3-12.

Lee, S. J. (2001). More than "model minorities" or "delinquents": A look at Hmong American high school students. Harvard Educational Review, 505-528.

Lew, J. (2006). Asian Americans in class. New York: Teacher College Press.

Masny, D. (1999). Weaving multiple literacies: Somali children and their teachers in the context of school culture. Language, Culture and Curriculum, 72-93.

McKay, S.L. (2006). Researching second language classrooms. Mahwah, NJ: Lawrence Erlbaum.

Moll, Luis, C., Amanti, C., Neff, D., \& Gonzalez, N. (1992). Funds of knowledge for teaching: using qualitative approach to connect homes and classrooms. Theory into Practice: $132-41$

Moore, J. R. (2006). Teaching about Islam in secondary schools: Curricular and pedagogical considerations. Equity \& Excellence in Education, 39, 279-286.

Norton, B. (2000). Identity and language learning: gender, ethnicity and educational change. Essex: Pearson Education.

Oikonomidoy, E. (2007). 'I see myslef as a different person who [has] acquired a lot . . .': Somali femaile students' journeys to belonging. Intercultural Education, Vol. 18, No. 1, 15-27. 
Olsen, L. (1997). Made in America: immigrant students in our public schools. New York: The New York Press.

Putman, Diana B. (1993). The Somalis: Their history and culture. CAL refugee fact sheet series, 9, 1-22.

Ramadan, T. (2007). What the West can learn from Islam. Chronicle of Higher Education, 53(24), B6-B8.

Reece, D. (1997). The gendering of prayer: An ethnographic study of Muslim women in the United States. Journal of Communication \& Religion, 20(1), 37-47.

Roberts, J. (2007). Wearing the hijab: An argument for moderate selective acculturation of newly immigrated Arab-American women. Journal of Intercultural Communication, from Communication \& Mass Media Complete database.

Robillos, M. U. (2001). Somali community needs assessment project: a report prepard for the Somali resource center. Minneapolis, MN: Minnesota University, Minneapolis Center for Urban and Regional Affairs.

Rumbaut, R. G. (2001). The forging of a new America: Lessons for theory and policy. Ethnicities: Children of immigrants in America, 301-317.

Schmidt, G. (2004). Islamic identity formation among young Muslims: The case of Denmark, Sweden and the United States. Journal of Muslim Affairs, 24(1), 31-43.

Stodolska, M. (2006). The influence of religion on the leisure behavior of immigrant Muslims in the United States. Journal of Leisure Research, 38(3), 293-320.

Stoessel, S. (2002). Investigating the role of social networks in language maintenance and shift. International Journal of Social Language, 153, 93-131.

Tarazi, N. (1995). The child in Islam: A Muslim parent's handbook. Plainfield, Indiana: American Trust.

Valdes, G. (1998). The world outside and inside school: language and immigrant students. Educational Researcher , 27 (6) 4-18.

White, M. J. (1997). Language usage, social capital, and school completetion among immigrants and native-born ethnic groups. Social Science Quarterly , 385-398.

Wilder Research Center. (2000). Speaking for themselves: A survey of Hispanic, Hmong, Russian, and Somali immigrants in Minneapolis-St.Paul. [Online] Available: www.wilder.org/research/reports.

Zine, J. (2000). Redefining resistance: toward an Islamic subculture in schools. Race Ethnicity and Education, 293-316.

Zine, J. (2001). Youth in Canadian schools: education and the politics of religious identity. Anthropology \& Education Quarterly, 399-423.

Zine, J. (2006). Unveiled sentiments: gendered Islamophobia and experiences of veiling among Muslim girls in a Canadian Islamic school. Equity \& Excellence in Education , 239-252. 


\section{Macrothink}

\section{Appendix}

Appendix 1. Interview Protocol

\section{Interview Protocol}

1. How and when did you get the idea to write your book?

a.How did you choose your audience? Why?

2. Overall, how would you describe the current school experience for Somali children?

3. In your book you state that you are an ESL/ELL teacher in the Minneapolis School District. How many years have you been teaching? In your opinion what is the best approach to teaching Somali children literacy skills such as speaking, listening, reading, and writing?

a.Should Somali children be taught to read and write in Somali?

4. What advice would you give a white teacher on how to advocate for Somali children and families?

5. If you could design a curriculum that considered the material, physical, psychological, and spiritual needs of Somali youth what would that look like?

a.How would it be different than what is currently taught in schools today?

6. On page 24 of your book you state, "In Somalia, parents were NEVER expected to participate at school, even regarding discipline issues.” Yet, multiple time in your book you talk about the importance of parental involvement. How do you envision parental involvement in the schools?

a. What would parental involvement look like at different grade levels?

7. American culture is so different from Somali culture. How can schools do a better job of informing parents...

a.how schools work

b. of their options

c.rights

8. On page 38 you give a vignette, of an art lesson gone wrong for the Somali students in the class due to being asked to draw a picture of people and animals. As a past elementary teacher I know that many, if not all, elementary writing curriculums ask students to draw a picture as a way to introduce writing a narrative. These drawings are then used to demonstrate how a writer develops a story. The students are asked to draw themselves, families, pets etc in these pictures. How would you change or modify this in order to respect the fact that Islam has banned the reproduction of the human image and the images of animals?

9. If you could design the perfect school for Somali, what would it look like? 